\title{
Effect of Metal Chelators on the Absorption Spectrum and on the Chlorpromazine Oxidase Activity of Ceruloplasmin
}

\author{
ROLF A. LøVSTAD
}

Institute of Medical Biochemistry, University of Oslo, Karl Johans gate 47, Oslo 1, Norway

In the presence of $\mathrm{NADH}$ and other reducing compounds (cysteine, reduced glutathione and ascorbate) the copper enzyme, ceruloplasmin, can bind bathocuproine and neocuproine, probably to one of the non-paramagnetic copper ions. An absorption band centered around 485 and $465 \mathrm{~nm}$ was associated with the enzymechelator complex in the case of bathocuproine and neocuproine, respectively. Experiments indicated that EDTA could bind to the same site on the enzyme molecule. The chelators investigated increased the chlorpromazine oxidase activity of ceruloplasmin in the presence of NADH, the activating effect increasing with increasing stability of the enzyme-chelator complex [bathocuproine $\left(K_{\mathrm{d}} \cong 0.2 \mu \mathrm{M}\right)>$ EDTA $\left(K_{\mathrm{d}}=8.5 \mu \mathrm{M}\right)>$ neocuproine $\left.\left(K_{\mathrm{d}}=19.3 \mu \mathrm{M}\right)\right]$. A considerably higher $V_{\text {max }}$-value was obtained in the presence of chelator, while the $K_{\mathrm{m}}$-value was slightly lowered.

Ceruloplasmin (coeruloplasmin, ferroxidase, EC 1.16.3.1) is a blue serum protein, containing several copper atoms, namely the paramagnetic Type-1 ("blue") Cu(II) and Type-2 ("non-blue") $\mathrm{Cu}$ (II) and non-paramagnetic copper, supposed to consist of strongly coupled $\mathrm{Cu}$ (II) $-\mathrm{Cu}$ (II) ions. ${ }^{1}$ Approximately half of the copper in ceruloplasmin is non-paramagnetic. The number of copper atoms bound to the ceruloplasmin molecule is still uncertain: values of six, ${ }^{2}$ seven, ${ }^{3}$ and eight ${ }^{4}$ atoms/molecule have been reported. Chelex-100 treatment of the protein results in the loss of one of the copper atoms. ${ }^{5}$ Ceruloplasmin has oxidase activity towards several compounds, such as aromatic diamines and diphenols, ${ }^{6-8}$ inorganic $\mathrm{Fe}$ (II), ${ }^{7-10}$ and drugs of the phenothiazine class. ${ }^{11}$ The enzyme is inhibited by the anions, azide and fluoride, ${ }^{12-14}$ which bind to Type-2 copper when the enzyme is in the resting state. ${ }^{13,14}$ In this communication it is shown that the copper chelating agents, bathocuproine, neocuproine and EDTA, readily bind to ceruloplasmin in the presence of $\mathrm{NADH}$ and other reducing compounds, changing the visible absorption spectrum of the enzyme and increasing its chlorpromazine oxidase activity.

\section{EXPERIMENTAL}

Materials. Human ceruloplasmin was purchased from AB Kabi and crystallized according to the method of Deutsch. ${ }^{15}$ The purified enzyme had an absorbance ratio, $A_{610} / A_{280}$, of 0.047 . Enzyme concentrations were calculated from the $610 \mathrm{~nm}$ absorption $\left(\varepsilon=10.9 \mathrm{mM}^{-1} \mathrm{~cm}^{-1}\right) .^{15}$ The enzyme was treated with Chelex-100, which removes one of the protein bound copper atoms ${ }^{5}$ without affecting the visible absorption spectrum and chlorpromazine oxidase activity of ceruloplasmin.

NADH, 2,9-dimethyl-1,10-phenanthroline (neocuproine) and 2,9-dimethyl-4,7-diphenyl1,10-phenanthroline-disulfonate (bathocuproine) were obtained from Sigma Chem. Co., EDTA and sodium azide from $E$. Merck AG and chlorpromazine from A/S Dumex. Aqueous solutions were prepared in deionized, glassdistilled water.

Measurement of enzyme activity. The chlorpromazine oxidase activity of ceruloplasmin was measured spectrophotometrically by adding NADH to the reaction mixture and recording the change in absorption at $340 \mathrm{~nm}$, due to the disappearance of NADH, which is spontaneously oxidized by free radicals generated from chlorpromazine. ${ }^{11}$ Appropriate corrections were made for a slow non-enzymic oxidation of NADH. Bathocuproine, neocuproine, and EDTA were incubated with enzyme and NADH for $10 \mathrm{~min}$ before adding chlorpromazine. Trace iron ions, which activate the reaction 


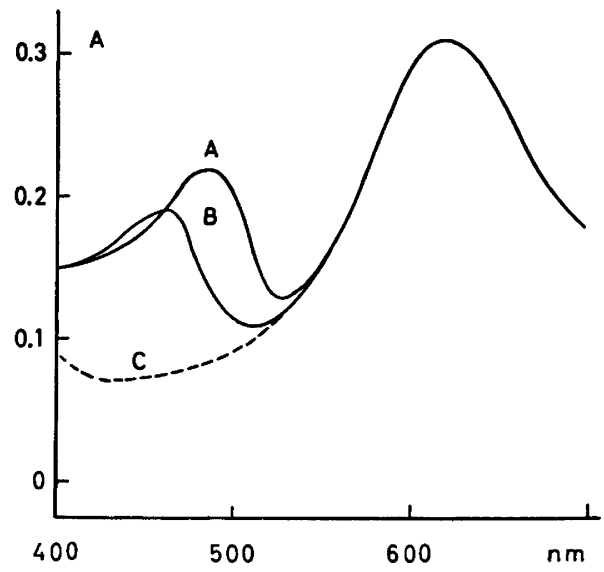

Fig. 1. Effect of bathocuproine (A) and neocuproine (B) on the visible absorption spectrum of Chelex-100 treated ceruloplasmin in the presence of $\mathrm{NADH}$. The solution contained $30 \mu \mathrm{M}$ ceruloplasmin, $0.5 \mathrm{mM}$ bathocuproine (0.8 $\mathrm{mM}$ neocuproine) and $1.6 \mathrm{mM} \mathrm{NADH}$ in $0.2 \mathrm{M}$ sodium acetate buffer, $\mathrm{pH}$ 5.5. C, Spectrum of ceruloplasmin alone.

between ceruloplasmin and several compounds, ${ }^{8}$ did not affect the enzymic oxidation of chlor. promazine.

Apparatus. Kinetic measurements and recordings of absorption spectra were performed in a Beckman DK-1 spectrophotometer, which was equipped with a thermo cell. The tempera. ture was kept at $30^{\circ} \mathrm{C}$ in all experiments.

\section{RESULTS}

Effect of chelators on the absorption spectrum of Chelex-100 treated ceruloplasmin. Absorption spectra in the visible region, recorded immediately after mixing ceruloplasmin with bathocuproine or neocuproine in the presence of $\mathrm{NADH}$, are shown in Fig. 1. The interaction between ceruloplasmin and bathocuproine leads to the appearance of a new absorption band with a maximum at $485 \mathrm{~nm}$. No significant change of the $610 \mathrm{~nm}$ chromophore of ceruloplasmin was observed. The $485 \mathrm{~nm}$ band also appeared when ceruloplasmin was incubated for $10 \mathrm{~min}$ with $2.8 \mathrm{mM}$ cysteine, reduced glutathione or ascorbate instead of NADH. Cysteine and ascorbate completely reduced the $610 \mathrm{~nm}$ chromophore of the enzyme without increasing the $485 \mathrm{~nm}$ absorption band in the presence of an excess of bathocuproine. When

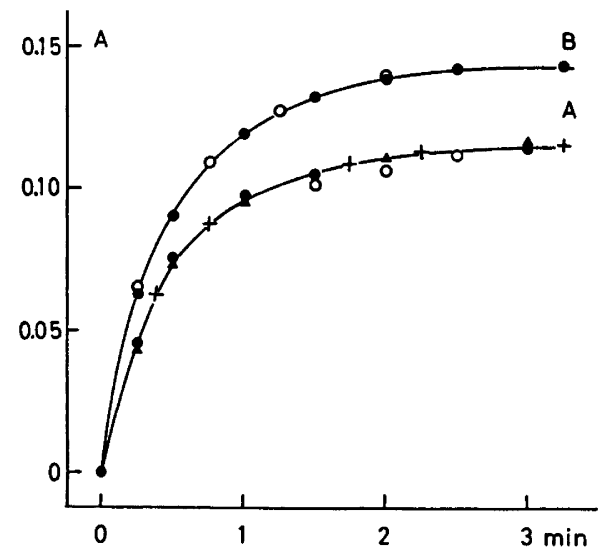

Fig. 2. Time course of the $485 \mathrm{~nm} \mathrm{(A)} \mathrm{and}$ $465 \mathrm{~nm}$ (B) absorbance changes observed on mixing bathocuproine and neocuproine, respectively, with Chelex-100 treated ceruloplasmin, incubated with NADH for $15 \mathrm{~min}$. A: The solution contained $25 \mu \mathrm{M}$ ceruloplasmin, $0.4 \mathrm{mM}$ bathocuproine and NADH $(0,15 \mathrm{mM}$; ,$+ 10 \mathrm{mM}$; O, $8 \mathrm{mM} ; \triangle, 5 \mathrm{mM}$ ) in $0.3 \mathrm{M}$ sodium acetate buffer, $\mathrm{pH}$ 5.5. B: The solution contained $39 \mu \mathrm{M}$ ceruloplasmin, $0.8 \mathrm{mM}$ neo. cuproine and $10 \mathrm{mM}$ NADH $(O$, $O$; two experiments) in $0.3 \mathrm{M}$ sodium acetate buffer, pH 5.5.

bathocuproine was substituted with neocuproine an absorption band centered around $465 \mathrm{~nm}$ appeared (Fig. 1). Azide (1 $\mathrm{mM}$ ) did not affect the formation of the new absorption bands, when incubated for $10 \mathrm{~min}$ with ceruloplasmin before adding NADH and chelator. Gel filtration experiments showed that the chelators did not remove copper from the Chelex-100 treated enzyme molecule.

Kinetics of the reaction between ceruloplasmin and chelators. Fig. 2 shows the formation of the $485 \mathrm{~nm}$ chromophore observed on adding bathocuproine to Chelex-100 treated ceruloplasmin, incubated with $\mathrm{NADH}$ for $15 \mathrm{~min}$. Another curve shows the formation of the $465 \mathrm{~nm}$ absorption band observed when neocuproine was added instead of bathocuproine. An excess of NADH ( $\geqq 5 \mathrm{mM}$ ) was used in order to make all the enzyme molecules available for chelator binding. The time course of the absorbance changes at $485 \mathrm{~nm}$ and $465 \mathrm{~nm}$ was not affected by variations in the $\mathrm{NADH}$ concentration in this case. Titration of ceruloplasmin with bathocuproine or neo- 


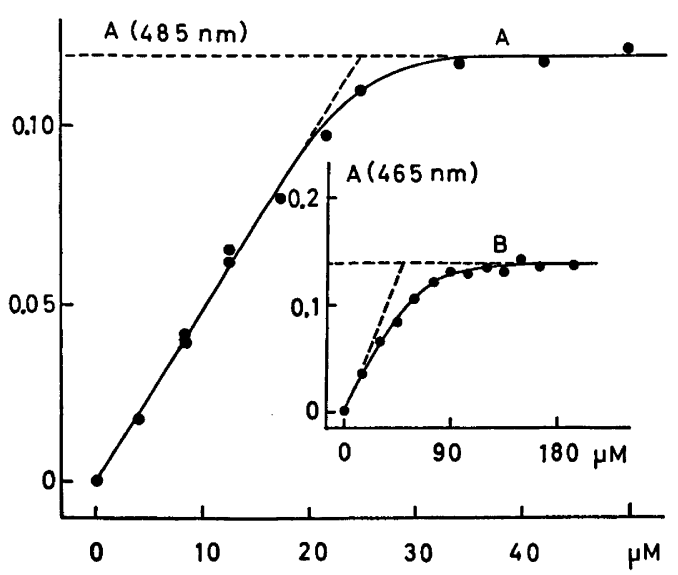

Fig. 3. Titration of Chelex-100 treated ceruloplasmin with bathocuproine (A) and neocuproine (B). Absorbance changes were determined $10 \mathrm{~min}$ after each addition of chelator to ceruloplasmin (25 $\mu \mathrm{M}(\mathrm{A}), 41 \mu \mathrm{M}$ (B)) and $10 \mathrm{mM} N A D H$ in $0.3 \mathrm{M}$ sodium acetate buffer, pH 5.5.

cuproine (Fig. 3) suggests that one chelator molecule is bound to the enzyme molecule. A molar absorption of $4.8 \mathrm{mM}^{-1} \mathrm{~cm}^{-1}(485 \mathrm{~nm})$ and $3.8 \mathrm{mM}^{-1} \mathrm{~cm}^{-1}(465 \mathrm{~nm})$ was calculated in the case of bathocuproine and neocuproine, respectively. The dissociation constant, $K_{\mathrm{d}}$, for the system

$\mathrm{CP}+\mathrm{Ch} \underset{k_{-1}}{\stackrel{k_{1}}{\rightleftharpoons}} \mathrm{CP}-\mathrm{Ch}$

(CP = ceruloplasmin, $\mathrm{Ch}=$ chelator $)$ was calcu lated and listed in Table 1. The concentration of ceruloplasmin in its free and chelator bound form was determined from the final absorbance reading at $485 \mathrm{~nm}$ or $465 \mathrm{~nm}$, using suitable concentrations of enzyme and chelators. The formation of the enzyme-chelator complex, recorded at $485 \mathrm{~nm}$ or $465 \mathrm{mn}$ (Fig. 2), followed second order kinetics initially, as indicated by the linear graphs obtained on plotting ln $\left(A_{\mathrm{t}} /\left(A_{\mathrm{t}}-A\right)\right) /\left(\left[\mathrm{Ch}_{0}\right]-\left[\mathrm{CP}_{0}\right]\right)$ against time (Fig. 4). The corresponding rate constant, $k_{1}$, was calculated from the slope of the line. $\left[\mathrm{Ch}_{0}\right]$ and $\left[\mathrm{CP}_{0}\right]$ represent concentrations at zero time, while $A_{\mathrm{t}}$ is the maximum absorption obtained with the amount of enzyme present. Several concentrations of enzyme, NADH and chelators (excess) were used. The rate constant for the splitting of the enzyme-chelator com-

Acta Chem. Scand. B 30 (1976) No. 9

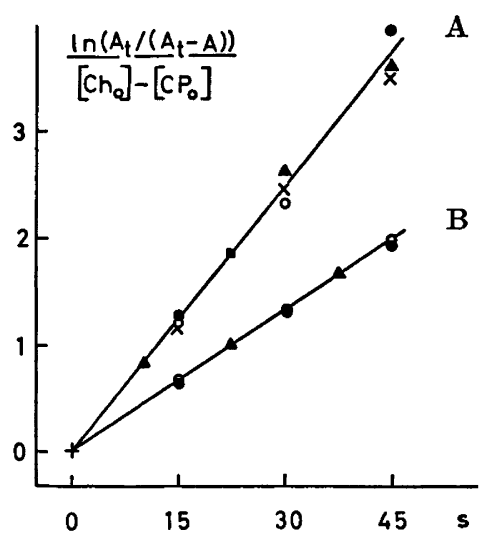

Fig. 4. Plots of $\ln \left(A_{\mathrm{t}} /\left(A_{\mathrm{t}}-A\right)\right) /\left(\left[\mathrm{Ch}_{0}\right]-\left[\mathrm{CP}_{0}\right]\right)$ $v s$. time for the formation of the ceruloplasminchelator complex. A:, $25 \mu \mathrm{M}$ enzyme and $15 \mathrm{mM}$ NADH; $\mathrm{O}, 25 \mu \mathrm{M}$ enzyme and $8 \mathrm{mM}$ $\mathrm{NADH} ; \Delta, 25 \mu \mathrm{M}$ enzyme and $5 \mathrm{mM} \mathrm{NADH}$; $\square, 15 \mu \mathrm{M}$ enzyme and $5 \mathrm{mM}$ NADH; $\times, 45 \mu \mathrm{M}$ enzyme and $8 \mathrm{mM}$ NADH. The bathocuproine concentration was $0.4 \mathrm{mM}$ in $0.3 \mathrm{M}$ sodium acetate buffer, $\mathrm{pH}$ 5.5. B: $0,0.8 \mathrm{mM}$ neocuproine; $O, 0.63 \mathrm{mM}$ neocuproine; $\Delta, 0.4 \mathrm{mM}$ neocuproine. The solutions contained $38 \mu \mathrm{M}$ ceruloplasmin and $10 \mathrm{mM} \mathrm{NADH}$ in $0.3 \mathrm{M}$ sodium acetate buffer, pH $\mathbf{5 . 5}$.

plex, $k_{-1}=K_{\mathrm{d}} k_{1}$, was also estimated. The constants are listed in Table 1.

When EDTA was added to a solution of ceruloplasmin, containing an excess of NADH and neocuproine, after all the enzyme is bound to neocuproine, a reduction of the $465 \mathrm{~nm}$ absorption band took place. Eventually a new steady state level was reached. It is assumed that EDTA competes with neocuproine for the binding site on ceruloplasmin. From the new steady state level the fraction of enzyme bound to neocuproine and to EDTA was determined. The amount of free enzyme was negligible, since large concentrations of chelators were used. The dissociation constant for EDTA was calculated from the equation $(\mathrm{NC}=$ neo. cuproine)

$K_{\mathrm{d}} \mathrm{EDTA}=K_{\mathrm{d}} \mathrm{NC} \frac{[\mathrm{CP}-\mathrm{NC}][\mathrm{EDTA}]}{[\mathrm{CP}-\mathrm{EDTA}][\mathrm{NC}]}$

and listed in Table 1.

Effect of chelators on the chlorpromazine oxidase activity of Chelex-100 treated ceruloplasmin. Bathocuproine, neocuproine, and 
Table 1. List of kinetic parameters.

\begin{tabular}{lcllll}
\hline Chelator & $\begin{array}{c}K_{\mathrm{d}} / \\
\mu \mathrm{M}\end{array}$ & $\begin{array}{l}k_{1} / \\
\mathrm{mM}^{-1} \mathrm{~min}^{-1}\end{array}$ & $\begin{array}{c}k_{-1} / \\
\mathrm{min}^{-1}\end{array}$ & $\begin{array}{l}K_{\mathrm{m} /} / \\
\mathrm{mM}\end{array}$ & $\begin{array}{c}V_{\text {max }} /[\mathrm{CP}] / \\
\mu \mathrm{M} \mathrm{NADH} / \mathrm{min}\end{array}$ \\
\hline Bathocuproine & $\sim 0.2$ & 5.0 & $\sim 0.001$ & 2.7 & 380 \\
Neocuproine & $19.3 \pm 1.4^{a}$ & $\mathbf{2 . 6}$ & 0.05 & 2.2 & 224 \\
EDTA & $8.5 \pm 1.5^{b}$ & & & 2.6 & 312 \\
No chelator & & & & $\mathbf{3 . 6}$ & $\mathbf{5 4}$ \\
\hline
\end{tabular}

${ }^{a}$ Average value of 12 determinations \pm SEM. ${ }^{b}$ Average value of 5 determinations \pm SEM.

EDTA have an activating effect on the ceruloplasmin-catalyzed oxidation of chlorpromazine in the presence of NADH, the order of effectiveness being bathocuproine $>$ EDTA $>$ neocuproine (Fig. 5). A sigmoidal curve is obtained when the activity is plotted against chelator concentration (Fig. 5). The activating effect increased with increasing NADH concentration, when an excess of chelator was present, suggesting that more NADH makes more enzyme molecules available for chelator binding. In the absence of chelator the reaction rate is independent of the NADH concentration. When NADH is omitted from the reaction solution the activity can be measured spectrophotometrically at $530 \mathrm{~nm}$ as the rate of chlorpromazine radical formation."11 In this case the chelators did not affect the oxidation rate, demonstrating that NADH is necessary for chelator activation. The effect of bathocuproine, neocuproine, and EDTA on the

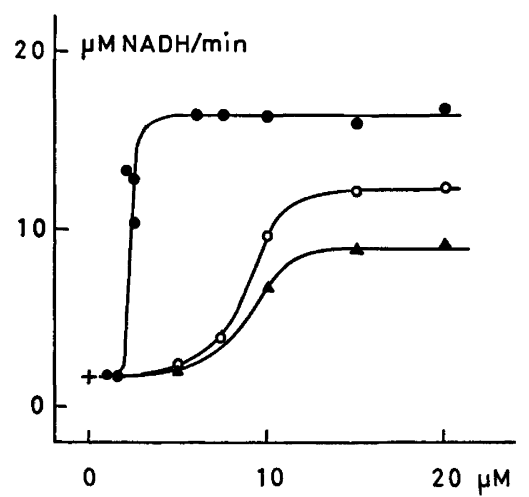

Fig. 5. Effect of bathocuproine (๑), EDTA $(O)$ and neocuproine $(\Delta)$ on the chlorpromazine oxidase activity of ceruloplasmin. The reaction mixtures contained $0.15 \mu \mathrm{M}$ ceruloplasmin, $1-20 \mu \mathrm{M}$ chelator, $0.25 \mathrm{mM} \mathrm{NADH}$ and $1 \mathrm{mM}$ chlorpromazine in $0.25 \mathrm{M}$ sodium acetate buffer, pH 5.5. +, Activity in the absence of chelator. oxidase activity of ceruloplasmin at different chlorpromazine concentrations was investigated and the results are presented in a double reciprocal plot (Fig. 6). The NADH concentration was kept constant in these experiments and maximum activation was obtained with the chelator concentrations used. The apparent Michaelis constants $\left(K_{\mathrm{m}}\right)$ and maximum activities $\left(V_{\max }\right)$ were calculated from the plot in Fig. 6 and listed in Table 1. $V_{\max }$ is markedly increased in the presence of chelators, while $K_{\mathrm{m}}$ is slightly decreased.

\section{DISCUSSION}

The experiments suggest that one of the ceruloplasmin copper atoms can bind bathocuproine, neocuproine, and EDTA after reduc-

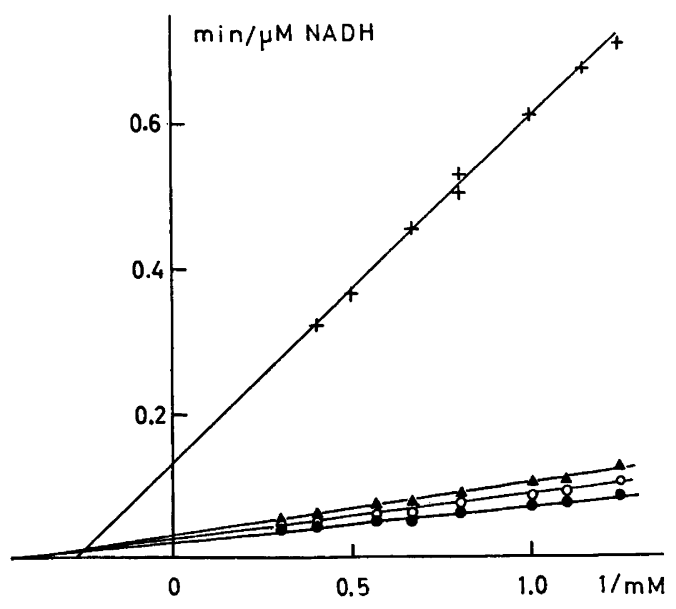

Fig. 6. The reciprocal activity plotted against the reciprocal chlorpromazine concentration in the absence $(+)$ and presence of chelators $(0,25 \mu \mathrm{M}$ bathocuproine; O, $25 \mu \mathrm{M}$ EDTA; $\Delta, 0.25 \mathrm{mM}$ neocuproine). The reaction mixtures contained $0.14 \mu \mathrm{M}$ ceruloplasmin, $0.3 \mathrm{mM}$ NADH and $0.8-3.3 \mathrm{mM}$ chlorpromazine in $0.3 \mathrm{M}$ sodium acetate buffer, $\mathrm{pH}$ 5.5.

Acta Chem. Scand. B 30 (1976) No. 9 
tion with NADH, cysteine, reduced glutathione or ascorbate. Studies by Carrico et al..$^{16} \mathrm{de}$ monstrated that ascorbate reduced both Type-1 and Type-2 $\mathrm{Cu}$ (II) as well as non-paramagnetic $\mathrm{Cu}$ (II). Bathocuproine and neocuproine are $\mathrm{Cu}(\mathrm{I})$-specific complexing reagents, giving rise to yellow chromophores on binding to inorganic $\mathrm{Cu}(\mathrm{I})$ or to Chelex-100 treated ceruloplasmin (Fig. 1). The observations that (1) the enzymechelator complex can be formed without altering the $610 \mathrm{~nm}$ chromophore of ceruloplasmin and that (2) cysteine and ascorbate completely reduce the $610 \mathrm{~nm}$ chromophore without increasing the concentration of the enzyme-chelator complex, when an excess of chelator is present, suggest that the "blue" Type-1 copper is not involved in chelator binding.

The Type-2 copper of ceruloplasmin has been reported to be essential for oxidase activity. ${ }^{1}$ Kinetic studies indicate that during reaction Type-2 copper is located between Type-1 and non-paramagnetic copper in the electron transport chain. ${ }^{17}$ Since the chelators investigated increase the enzyme activity (Fig. 5), and since azide, which binds to Type-2 copper, ${ }^{13}$ does not inhibit the formation of the NADH dependent enzyme-bathocuproine (neocuproine) complex, it seems unlikely that the chelators bind to the Type-2 copper. Therefore it is probable that the complexing compounds react with one of the non-paramagnetic copper ions, and that this ion is not involved in the catalytic process.

Ceruloplasmin forms an especially stable complex with bathocuproine; the dissociation of which is characterized by a low rate constant (Table 1). Bathocuproine was also the best activator of the reaction between ceruloplasmin and chlorpromazine. The activating effect of the chelators was found to decrease with decreasing stability of the enzyme-chelator complex (bathocuproine $>$ EDTA > neocuproine) (Table 1). The sigmoidal activation curves shown in Fig. 5 cannot be accounted for at present. This type of curve is usually associated with positive cooperativity of the effector molecules. The increased $V_{\max }$-values obtained for the ceruloplasmin-catalyzed oxidation of chlorpromazine in the presence of chelators and NADH (Table 1), suggest that the chelator bound enzyme molecules have an increased rate of product formation from the enzyme-substrate (product) complex. The lower $K_{m}$-values obtained in the presence of chelators indicate that they also increase the enzyme affinity for chlorpromazine.

The observation that bathocuproine readily binds to ceruloplasmin in the presence of ascorbate and SH-containing compounds, could mean that the copper ion on the chelator binding site is reduced, when ceruloplasmin is circulating in the blood.

Acknowledgements. The author thanks Professor O. Walaas, Dosent E. Walaas and Dosent J. McKinley-McKee for their help and interest and A/S Dumex for the gift of chlorpromazine. This work was supported by grant from A. Jahres Fond and E. Langfeldts Fond.

\section{REFERENCES}

1. Malkin, R. and Malmström, B. G. Adv. Enzymol. Relat. Areas Mol. Biol. 33 (1970) 177.

2. Magdoff-Fairchild, B., Lovell, F. M. and Low, B. W. J. Biol. Chem. 244 (1969) 3497.

3. Aisen, P., Koenig, S. H. and Lilienthal, H. R. J. Mol. Biol. 28 (1967) 225.

4. Holmberg, C. G. and Laurell, C.-B. Acta Chem. Scand. 2 (1948) 550.

5. McKee, D. J. and Frieden, E. Biochemistry 10 (1971) 3880 .

6. Holmberg, C. G. and Laurell, C.-B. Acta Chem. Scand. 5 (1951) 476.

7. Frieden, E. and Hsieh, H. S. Adv. Enzymol. Relat. Areas Mol. Biol. 44 (1976) 187.

8. MeDermott, J. A., Huber, C. T., Osaki, S. and Frieden, E. Biochim. Biophys. Acta 151 (1968) 541.

9. Curzon, G. and O'Reilly, S. Biochem. Biophys. Res. Commun. 2 (1960) 284.

10. Osaki, S., Johnson, D. A. and Frieden, E. J. Biol. Chem. 241 (1966) 2746.

11. Løvstad, R. A. Biochem. Pharmacol. 23 (1974) 1045.

12. Curzon, G. and Speyer, B. E. Biochem. J. 105 (1967) 243.

13. Andréasson, L.-E. and Vänngård, T. Biochim. Biophys. Acta 200 (1970) 247.

14. Brändén, R., Malmström, B. G. and Vänngård, T. Eur. J. Biochem. 36 (1973) 195.

15. Deutsch, H. F. Arch. Biochem. Biophys. 89 (1960) 225.

16. Carrico, R. J., Malmström, B. G. and Vänngård, T. Eur. J. Biochem. 20 (1971) 518.

17. De Ley, M. and Osaki, S. Biochem. J. 151 (1975) 561 .

Received April 28, 1976.

Acta Chem. Scand. B 30 (1976) No. 9 